\title{
Clinicopathological features of pilomatricoma cases: Analysis of 21 cases
}

\author{
Ghartimagar $\mathrm{D}^{1}$, Ghosh $\mathrm{A}^{1}$, Gautam $\mathrm{K}^{2}$, Thapa $\mathrm{S}^{1}$, Shrestha SR ${ }^{1}$, Narasimhan $\mathrm{R}^{1}$ \\ ${ }^{I}$ Department of Pathology, Manipal Teaching Hospital, Phulbari, Pokhara, Nepal \\ ${ }^{2}$ Department of Pathology and Laboratory Medicine, Grande International Hospital, Dhapasi, Kathmandu, Nepal
}

\section{Keywords: \\ Ghost cell; \\ Pilomatricoma; \\ Skin neoplasm; \\ Ossification.}

\begin{abstract}
Background: Pilomatricoma is a slow-growing, asymptomatic tumour originating from outer sheath cells of hair follicle. In this study, we describe the clinical presentation and histopathological features of pilomatricoma.

Materials and Methods: This was a hospital based retrospective study carried out in all patients who were diagnosed as pilomatricoma over a period of January 2001 to December 2013. The study was done in department of pathology, Manipal Teaching Hospital, Nepal.

Results: A total of 21 cases of pilomatricoma were reported with age range of 9-53 years (mean age 23.7) and male female ratio of $1: 1.1$. The most common site of occurrence was neck and preauricular region. The size of the tumour ranged from 0.3 to $4.7 \mathrm{~cm}$ with a mean of $1.2 \mathrm{~cm}$. Multiple occurrences were seen in 3 patients and ossifying pilomarticoma was seen in 4 cases.

Conclusion: Pilomatricoma is a benign skin neoplasm of hair follicle matrix cells. Calcification is a common finding while dystrophic ossification also can occur in the tumour. Histopathology gives the definite diagnosis as fine needle aspiration cytology and clinical impression may be misleading.
\end{abstract}

\section{INTRODUCTION}

Pilomatricoma, also known as calcifying epithelioma of Malherbe, is a skin appendageal tumour seen in head and neck regions. ${ }^{1}$ It is usually slow-growing, asymptomatic tumour which originate from outer sheath cells of hair follicle and are generally seen in children and adolescents. Clinically, they present as well-circumscribed, rigid, 5-30 $\mathrm{mm}$ in size, deep dermal and subcutaneous masses. Usually they are solitary nodule but multiple and familial cases are also reported. Diagnosis is made by histopathological

\section{Correspondence:}

Dr. Dilasma Ghartimagar,MD

Assistant Professor, Department of Pathology

Manipal Teaching Hospital, Pokhara, Nepal

E-mail:dilasmagm@hotmail.com examination of the excisional biopsy. ${ }^{2,3}$

\section{MATERIALS AND METHODS}

This is a hospital based retrospective study carried out in department of pathology, Manipal Teaching Hospital over a span of 13 years (from January 2001 to December 2013). The study included all cases who were diagnosed as pilomatricoma on histopathology. All the clinical, histopathological and pre-excision find needle aspiration cytology (FNAC) data were retrieved and collected from the departmental data bank and were analyzed. The histopathology tissues were routinely fixed with $10 \%$ formalin and the slides were stained with H\&E stains. Decalcification was done whenever required. 


\section{RESULTS}

A total of 21 cases of pilomatricoma tumours have been reported on histopathology in the same period. Male to female ratio was $1: 1.1$ with $10(47.6 \%)$ cases seen in male patients and 11(52.4\%) cases in female cases. Age range was from 9 to 53 years with a mean age of 23.7 years and $10(47.6 \%)$ cases occurring in less than 20 years of age. The most common site of occurrence was neck $(\mathrm{N}=4)$ and preauricular region $(\mathrm{N}=4)$ followed by cheek $(\mathrm{N}=3)$ and 2 cases each from scalp and eye lid (Table 1). The tumour size ranged from 0.3 to $4.7 \mathrm{~cm}$ with a mean of $1.2 \mathrm{~cm}$. Multiple occurrences were seen in 3 patients. One patient presented with 3 nodules in the neck, one with 2 nodules in the scalp and the remaining one patient with 2 nodules in the scalp and left knee. Preoperative FNAC was performed in 10 cases. The correct preoperative diagnosis was given in only 1 case. The other 9 cases were misdiagnosed as epidermal inclusion cyst. Ossification/ ossifying pilomatricoma was seen in 4 cases. Preoperative clinical impressions were sebaceous cyst $(\mathrm{N}=11)$, lymph node $(\mathrm{N}=6)$, lipoma $(\mathrm{N}=1)$ and preauricular sinus with abscess $(\mathrm{N}=1)$ and inconclusive $(\mathrm{N}=2)$.

\section{DISCUSSION}

Pilomatricoma, a benign neoplasm of the hair follicle, was initially thought to arise from sebaceous glands and was called calcifying epithelioma of Malherbe by Malherbe and Chenantais in $1880 .{ }^{4}$ In 1961, after histochemical and electron microscopic analysis of 228 such tumours, Forbis and Helwig found the cell of origin to be the outer root sheath cell of the hair follicle and proposed the name, pilomatrixoma, now called pilomatricoma. ${ }^{5}$

The most common location is the head and neck region, followed by the upper extremities, the trunk, and the lower extremities. ${ }^{6}$ In the head and neck region, the most frequent locations are the neck and the frontal, temporal, periorbital,

Table 1: Distribution of sites of pilomatricoma cases

\begin{tabular}{lc}
\hline \multicolumn{1}{c}{ Sites } & No of cases \\
\hline Neck & $4(25.4 \%)$ \\
\hline Preauricular region & $4(25.4 \%)$ \\
Cheek & $3(14.3 \%)$ \\
Scalp & $2(9.5 \%)$ \\
\hline Eyelid & $2(9.5 \%)$ \\
\hline Forehead & $1(4.7 \%)$ \\
\hline Shoulder & $1(4.7 \%)$ \\
\hline Arm & $1(4.7 \%)$ \\
\hline Forearm & $1(4.7 \%)$ \\
\hline Thigh & $1(4.7 \%)$ \\
\hline knee & $1(4.7 \%)$ \\
\hline Total & $\mathbf{2 1}$ \\
\hline
\end{tabular}

and preauricular areas. ${ }^{7,8}$ In our study also, we found 4 cases in neck and preauricular region. There were 3 cases in cheek and 2 cases each in scalp and eyelid. Sixty percent of the cases arise in the first two decades of life. The tumour usually varies in diameter from 0.5 to $3.0 \mathrm{~cm} .{ }^{9}$ Our study showed mean age of $23.7 \mathrm{yrs}$ and $10(47.6 \%)$ cases seen below 20 years of age. The tumour size ranged from 0.3 to $4.7 \mathrm{~cm}$ which corroborates well with other studies.

Clinically, it presents as a firm, deep-seated nodule that is covered by normal skin. ${ }^{9}$ Though they are usually solitary, but multiple occurrences have been reported in $2 \%$ to $10 \%$ in different series. ${ }^{10,11}$ In our study, there were $3(14.9 \%)$ cases of multiple pilomatricomas (neck, scalp and left knee). The female-male ratio ranged from $0.43: 1$ to $2.45: 1$, and a female preponderance was noted in a majority of other studies. ${ }^{7,8}$ Our study, also showed a marginal female preponderance ( $\mathrm{F}: \mathrm{M}=1.1: 1)$. The tumour is usually asymptomatic and grows slowly over a period of several months or years. The clinical differential diagnosis of head and neck pilomatricoma includes sebaceous cyst, ossifying hematoma, preauricular sinuses, giant cell tumour, dermoid cyst, degenerating fibroxanthoma, foreign body reaction, and osteoma cutis. ${ }^{7,8,12}$ In our study, the clinical diagnoses were sebaceous cyst, lymphnode, lipoma and preauricular sinus with abscess.

Grossly, the nodules showed grey white surface with chalky white areas (fig. 1). Histopathological examination showed sharply demarcated dermal nodule surrounded by a capsule of compressed fibrous tissue. The cells in the islands are arranged in a circular configuration, with nucleated basaloid cells on the periphery and enucleated shadow cells in the centre (fig. 2). The shadow cells, also termed ghost cells, represent dead cells that retain their cellular shape and show a central unstained area that corresponds to the lost nucleus. Calcification is mostly seen in the ghost cell regions, with the incidence ranging from $69 \%$ to $85 \%$ while areas of dystrophic ossification are seen in $15-20 \%$ of cases. ${ }^{5,9,10}$ Our study showed 4(19.04\%) cases of dystrophic ossification (fig. 3 \&fig. 4) and was reported as "ossifying pilomatricoma" which correlates well with other studies. Foreign body giant cell reaction, which represents a granulomatous response to the shadow cells, can also be identified in regions where keratinized debris is abundant. ${ }^{9,11,13}$ Giant cell reaction in pilomatricoma was reported in $2(9.5 \%)$ cases of our study.

FNAC has been described as a preoperative diagnostic investigation. However, the results can be misleading if there are no ghost cells present in the aspirate. ${ }^{7,8}$ We diagnosed only one case of pilomatricoma with FNAC in a 13 year old girl with a right cheek swelling. Smears showed anucleated cells along with darkly stained basaloid cells and few giant cells. The other cases showed only anucleated squames leading to the impression of epithelial inclusion cyst.

Since spontaneous regression is never observed, the standard 


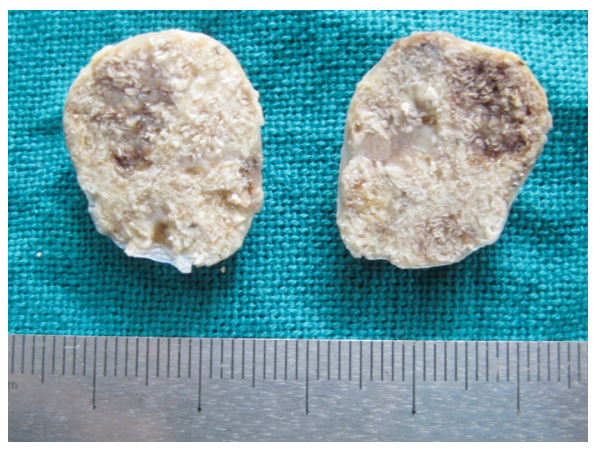

Figure 1: Gross picture showing grey white surface with areas of calcification



Figure 3: Areas of dystrophic calcification and ossification. (HE stain, X100).

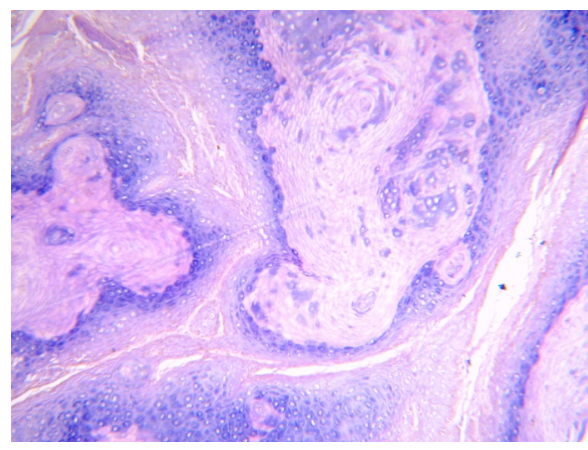

Figure 2: Islands of basaloid cells with central area showing ghost cells (HE stain, X100).

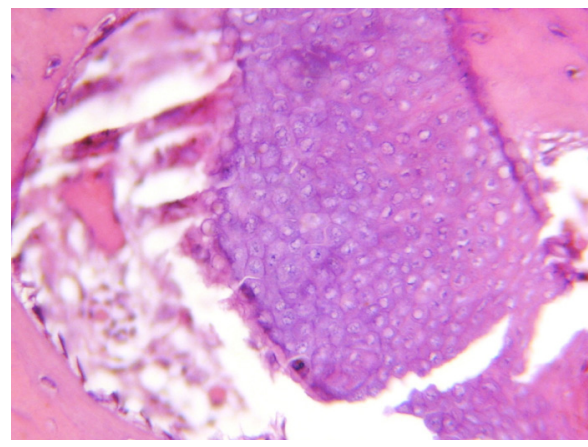

Figure 4: High power view showing ossified area and ghost cells (HE stain, X400). treatment of pilomatricoma is complete surgical excision. ${ }^{8,11}$ Recurrences after surgery are rare, with an incidence of $0 \%$ to $3 \% .4,10,14$ Malignant transformation of pilomatricoma is rare, with fewer than 20 cases described in the literature. ${ }^{7,11}$ Malignant pilomatricomas tend to occur in middle-aged to elderly patients. ${ }^{6}$ We did not have any malignant cases of pilomatricoma.

\section{CONCLUSION}

Pilomatricoma is a slow growing, firm and benign skin neoplasm that arises from the hair follicle matrix cells. This tumour typically occurs in head and neck regions in children and young adults. Calcification is a common finding while dystrophic ossification also can occur in the tumour. Histopathology gives the definite diagnosis as FNAC and clinical impression may be misleading.

\section{REFERENCES}

1. Gupta R, Verma S, Bansal P, Mohta A. Pilomatrixoma of the Arm: A Rare Case with Cytologic Diagnosis. Case Reports in Dermatological Medicine Volume 2012.

2. Yuca K, Kutluhan A, Cankaya H, Akman E. Giant pilomatrixoma arising in the preauricular region: a case report. Kulak Burun Bogaz Ihtis Derg 2004;12:147-9. PMid:16020991
3. Williams MD, Pearson MH, Thomas FD. Pilomatrixoma: a rare condition in the differential diagnosis of a parotid swelling. Br J Oral Maxillofac Surg 1991;29:201-3. CrossRef

4. Malherbe A, Chenantais J. Note sur l'e'pithe'lioma calcifie'des glandes se'bace'es. Prog Med 1880;8:826-37.

5. Forbis R, Helwig EB. Pilomatrixoma (calcifying epithelioma). Arch Dermatol 1961;83:606-17.CrossRef

6. Lan MY, Lan MC, Ho CY, Li WY, Lin CZ. Pilomatricoma of the head and neck: A retrospective review of 179 cases. Arch Otolaryngol Head Neck Surg 2003;129:1327-30. CrossRef

7. Cohen AD, Lin SJ, Hughes CA, An YH, Maddalozzo J. Head and neck pilomatrixoma in children. Arch Otolaryngol Head Neck Surg 2001;127:1481-3. CrossRef

8. Agarwal RP, Handler SD, Matthews MR, Carpentieri D. Pilomatrixoma of the head and neck in children. Otolaryngol Head Neck Surg 2001;125:510-5. CrossRef

9. Klein W, Chan E, Seykora JT. Tumours of the epidermal appendages. In: Elder DE, Elenitsas R, Johnson BL, Murphy GF, editors. Lever's histopathology of the skin. 9th ed. Philadelphia: Lippincott Williams and Wilkins; 2005. 867-926pp. 
10. Yencha MW. Head and neck pilomatricoma in the pediatric age group: a retrospective study and literature review. Int J Pediatr Otorhinolaryngol 2001;57:123-8. CrossRef

11. Duflo S, Nicollas R, Roman S, Magalon G, Triglia JM. Pilomatrixoma of the head and neck in children. Arch Otolaryngol Head Neck Surg 1998;124:1239-42. CrossRef

12. Thomas RW, Perkins JA, Ruegemer JL, Munaretto JA. Surgical excision of pilomatrixoma of the head and neck. Ear Nose Throat J
1999;78:541-8. PMid:10485145

13. Goufman LTDB, Murrell CDRGL, Watkins CDRDV. Quiz case 2: diagnosis: pilomatricoma (calcifying epithelioma of Malherbe). Arch Otolaryngol Head Neck Surg 2001;127:218-20. PMid:11177046

14. Ioannidis O, Stavrakis T, Cheva A, Papadimitriou N, Kotronis A, Kakoutis E. Pilomatricoma of the arm with extensive ossification. Adv Med Sci 2010;55:340-2. CrossRef 